\title{
A EQUIVALÊNCIA ENTRE ONOMATOPEIAS E CARTÕES COM EMOÇÕES
}

\author{
Carlos Henrique Berg ${ }^{1}$, Msc. \\ Vânia Ulbricht ${ }^{2}$, Dra. \\ Tarcísio Vanzin ${ }^{3}$, Dr. \\ Luciane Fadel ${ }^{4}$, Dra.
}

(1) Universidade Federal de Santa Catarina e-mail: henrique.berg@gmail.com

(2) Universidade Federal de Santa Catarina e-mail: vrulbricht@gmail.com

(3) Universidade Federal de Santa Catarina e-mail:tvanzin@gmail.com

(4) Universidade Federal de Santa Catarina e-mail: liefadel@gmail.com

Key-words: Usability test, Onomatopoeia, Blind people

Abstract

This research discusses the accessibility of emotional perception assessment methods on digital interfaces. Thus, this research seeks to include participants with visual impairments in interface evaluation tests. The first step was a systematic review of literature on human spatial representations. The results suggest that the sense of touch and hearing can be regarded as the two main ways that people with visual impairment use to create spatial representations. The spatial representation is important for navigation, for the representation of forms in the nature and in the learning process. Following the systematic review, this article reports the selection, by the audience of interest, the onomatopoeias perceived as equivalent to emotion cards. The result of the evaluation was the creation of an onomatopoeic prototype. 


\section{$16^{\circ}$ \\ ERGODESIGN USIHC CINAHPA}

$16^{\circ}$ Ergodesign - Congresso Internacional de Ergonomia e Usabilidade de Interfaces Humano Tecnológica: Produto, Informações Ambientes Construídos e Transporte

$16^{\circ}$ USIHC - Congresso Internacional de Ergonomia e Usabilidade de Interfaces Humano Computador

CINAHPA | 2017 - Congresso Internacional de Ambientes Hipermídia para Aprendizagem.

Palavras-chave: Testes de usabilidade, Onomatopeia, Pessoas cegas

Resumo

Essa pesquisa discute a percepção da acessibilidade em métodos de avaliações de interfaces digitais. Ela visa incluir participantes com deficiência visual em avaliações de interfaces. Iniciou com uma revisão sistemática de literatura sobre representações espaciais humanas. Os resultados sugeriram que o tato e a audição podem ser os principais sentidos usados para a criação da representação especial em pessoas com deficiência visual. As representações são importantes para a navegação, para a representação das formas da natureza e no processo de aprendizagem. Seguindo a revisão sistemática, e considerando o sentido da audição, esse artigo relata a escolha de onomatopeias percebidas como equivalente aos cartões com emoções pelo publico de interesse. $O$ resultado dessa avaliação foi a criação de um protótipo onomtopeico.

\section{Introduction}

For its capacity of adaptability and possibility to transmit content in the form of hypermedia, Internet widens access to this information. That is why teachers and researchers develop Learning Management Systems - LMS, in order to offer learning opportunities to as many people as possible including people with some type of disability. As an example of the adaptability of the Internet it is possible to upload videos with contents in LIBRAS (Brazilian Portuguese sign language) or sign language and text, which can be used by people with hearing impairments. In the case of people with visual impairment, screen readers, audio description and reading texts can be used to navigate and apprehend the content.

All this content is mediated with humans through interfaces, which are often based on metaphors. However, such metaphors may not be quite recognizable and thus present barriers to understanding and navigation. For those people with disabilities, metaphors may not make sense at all as they do not have the same references (visual, spatial, structural, etc.) as those with normal vision. Therefore, investigating these barriers is important to build interfaces with high satisfaction among people with disabilities.

These investigations might be carried out using four paradigms of assessment of human computer interaction: computerized procedures, inspection by experts, heuristic evaluations and usability tests [1]. Computerized procedures are automatic processes that read the environment in search of accessibility errors and are based on international standards and recommendation as the WCAG 1.0 [2] and 2.0 [3]. Use of screen readers, applications that read the page aloud might also be used for searching for errors.

Experts are used in two paradigms, inspection and heuristic evaluations. Expert inspection is made by an expert in the area who navigates the environment searching for errors. Also used by specialists, the heuristics are recommendations lists created from best practices or based on research with experts. As an example, one can mention the ten golden rules of Nielsen [4], [5] or the eight recommendations of Bastien \& Scapin [6] to evaluate the environment.

Usability tests are the only ones of these four paradigms that evaluate the HCI with the real user. Usability test collect data about efficiency, effectiveness and sometimes satisfaction. But efficiency and effectiveness are numerical data, like time, quantity of errors, etc., which not reflect user perceptions. Therefore, some of the content is lost, not presenting a broad spectrum of evaluation.

Concomitant to these measures, a satisfaction questionnaire is often applied after the usability tests. The evaluation of the results of the questionnaire usually depends on the evaluator and can present detours caused by the subjectivity of 


\section{$16^{\circ}$ \\ ERGODESIGN USIHC CINAHPA}

the analysis. Therefore, these usability tests might present limitations because the feelings have to be translated into language.

To overcome these limitations, many researchers are investigating different forms to better understand and measure the aspirations, needs and desires of the users. Many researchers (ANCKER, CHAN and KUKAFKA, 2012; KATSIONIS, VIRVOU, 2005; AGARWAL, MEYER, 2009; TZVETANOVA, TANG and JUSTICE, 2007; and SAUER, SONDEREGGER, 2008) [7], [8], [9], [10], [11] point out the limitations of these methods that do not consider user's emotions, but are based mainly on scenarios where group discussions are reviewed informally.

Some of these researchers have demonstrated that emotion has a significant impact on interaction.

Agarwal and Meyer (2009) claim that humans are more efficient and creative in solving problems when they are happy. Sauer and Sonderegger (2008) add that the concepts of joy, pleasure, fun and satisfaction about a task should be considered when evaluating interactions. Tzvetanova, Tang and Justice (2007) state that positive emotions affect memory, motivation and a sense of commitment to what you do.

In order to capture which emotion is perceived by the users when interacting with the system, it was developed a tool named Emocard (DESMET, 2003), the figure 1.

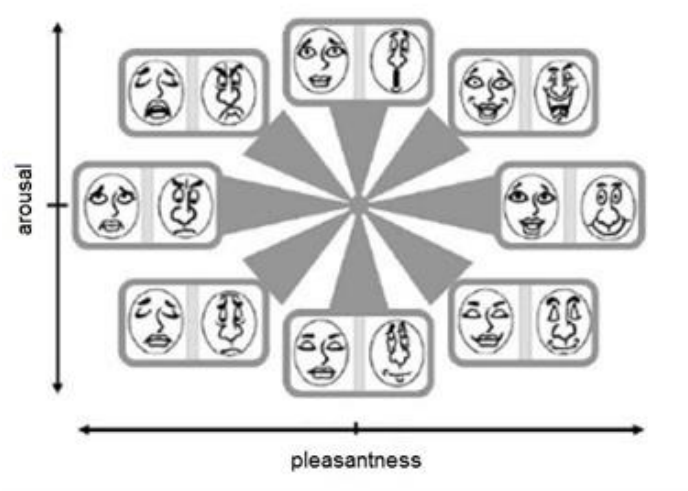

Figure 1 - Emocard

Font: Desmet, 2003

This tool has been tested with non-disabled people $16^{\circ}$ Ergodesign - Congresso Internacional de Ergonomia e Usabilidade de Interfaces Humano Tecnológica: Produto, Informações Ambientes Construídos e Transporte

$16^{\circ}$ USIHC - Congresso Internacional de Ergonomia e Usabilidade de Interfaces Humano Computador

CINAHPA | 2017 - Congresso Internacional de Ambientes Hipermídia para Aprendizagem.

and people with hearing and visual disabilities (BERG et al, 2012; BERG, 2013) demonstrating success both in use by research subjects, as in the evaluation of the virtual accessible learning environment WebGD.

However, this method, as well as similar ones that use images, offers a natural barrier for people with visual impairment. This model prevents its use by blind people and curtails the possibility for them to evaluate the environments or products which they use. In order to understand how these people could express an opinion on environments and products, a systematic literature review (BERG, FLORES, ULBRICHT e FADEL, 2016) which sought the main ways that people with visual impairment use to build spatial representations was made.

People with visual impairment, according to the review, build spatial representations mainly using touch and also sounds and descriptions of objects. Haptic sensations have also been cited as a way of building spatial representations.

In the case of the blind, touch is the most used sense because by touching objects they can locate themselves in space and using Braille writing helps them to compose a repertoire of pictures and mental maps. Hearing also composes a large channel for creation of spatial representations because blind people can hear the narratives and explanations of other people, as well as allowing them to use screen readers in computers.

In addition, some researchers (RÖDER, B. e RÖSLER, 2003) show evidence of a cross-modal plasticity in blind subjects, in which the occipital areas are recruited by non-visual stimuli, which may be organised in modular form. Due to loss of a sensory system, performance of this ability changes the functions of long-term memory, demonstrating a high adaptive capacity for the human cognitive system. Studies on brain imaging showed activation patterns in blind people, which compared with sighted individuals suggest reorganization in multisensory areas and brain regions, initially associated with the process of vision, and can help to improve the skills of the blind (RÖDER, B. e RÖSLER, 2003). Röder and
Realização:

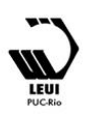




\section{$16^{\circ}$ \\ ERGODESIGN USIHC CINAHPA}

Rösler (2003) state that studies gave evidence about compensatory abilities of memory for auditory stimuli, which are activated soon after the loss of vision. Thus, this paper seeks the equivalence of onomatopoeia compared to images in emotion perception tests. In this experiment, 34 participants were asked to choose one onomatopoeia for each group of emotion recorded with male and female voices.

\section{Method}

This study is a qualitative research which explores possibilities of blind people to participate in emotions perception tests. Thus the experiment was designed using the DECIDE method proposed by Preece, Rogers and Sharp (2002) for planning evaluations with users of products, systems or interfaces.

As part of the methodology, a statistical method was used without a control group for an evaluation of attitudes, after exposing the subject to experiment (MATTAR, 1999).

The onomatopoeias were based on the Emocard's emotions (DESMET, 2003) and were evaluated by the research subjects. Results are presented by the use of tables and images, followed by the analysis.

\section{DECIDE FRAMEWORK}

The DECIDE framework allows to detect interface problems prior to launch and allows a valid structure for future versions (TOGNAZZINI, 1992). DECIDE (PREECE, ROGERS and SHARP, 2002) is an acronym for:

Determine the goals

Explore the questions

Choose the evaluation paradigm and techniques

Identify the practical issues

Decide how to deal with the ethical issues

Evaluate, interpret, and present the data $16^{\circ}$ Ergodesign - Congresso Internacional de Ergonomia e Usabilidade de Interfaces Humano Tecnológica: Produto, Informações Ambientes Construídos e Transporte

$16^{\circ}$ USIHC - Congresso Internacional de Ergonomia e Usabilidade de Interfaces Humano Computador

CINAHPA | 2017 - Congresso Internacional de Ambientes Hipermídia para Aprendizagem.

\subsection{Determine the goals}

There are various techniques and methods used in usability tests which use emotion (All About UX http://www.allaboutux.org/). However, they are mainly visual, which prevents its use by blind or visually impaired people. Based on this consideration, the goal to be achieved is to check if the illustrations of emotions contained in these methods can have their equivalence with other non-visual tools.

\subsection{Explore the questions}

According to the literature review, blind or visually impaired people formed space representations, primarily using touch and then sounds and descriptions of objects. Haptic sensations have also been cited as a way of building the spatial representations. Based on this knowledge about ways to construct the spatial representations, the authors conjectured on the possibility of using onomatopoeia instead of emotion cards. Therefore, the question of research focuses on finding the best onomatopoeia equivalent to Emocard's emotions.

\subsection{Choose the evaluation paradigm and techniques}

Desmet (2003) developed a self-report tool that uses images of emotions to evaluate products and environments. The Emocard tool shows eight images with expressions of human emotions in a cardboard within the parameters of excitement and enchantment.

The technique chosen to evaluate the environment commonly uses two steps. On the first one, the user was asked to look freely at the Emocard. After this initial period of experimentation, the researchers asked the users to use an onomatopoeia according to the emotion in the Emocard.

Thirty-four graduate students without disabilities participated in the experiment to suggest one or more onomatopoeias for each emotion. The suggestions were grouped by similarity, as shown in Figure 2.
Realização:

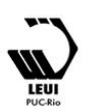




\begin{tabular}{|c|c|c|c|c|c|c|c|}
\hline 0 & 1 & 2 & 3 & 4 & 5 & 6 & 7 \\
\hline$\frac{\partial}{x}$ & 兔 & 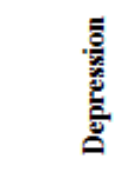 & $\frac{}{6}$ & z: & 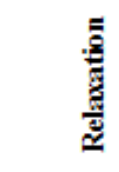 & 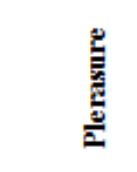 & 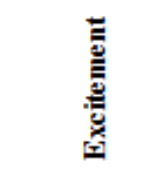 \\
\hline aaaah & humf & oh & $\mathrm{hm}$ & oh & ziii & heheh & haha \\
\hline aaaah & HUMPF & Ooow & $\mathrm{hmm}$ & oh & $z z z$ & HEHEHE & haha! \\
\hline aarrr & humpf & oum & $\mathrm{hmm}$ & oh & zzzz! & hehehe & HAHAHA \\
\hline Aff. & hunf & ounu & hmmm... & $\mathrm{OH} !$ & $z z z z z$ & hehehe & hahaha \\
\hline $\mathrm{ahl}$ & humf & ow & HUM & ohl & $z z z z z$ & hehehehe & Hahahal \\
\hline
\end{tabular}

Figure 2 - Grouping of onomatopoeias Font: Berg, Fadel and Ulbricht, 2014

After the grouping was concluded, it was necessary to record in a studio using male and female voices to verify if the blind could establish the equivalence between the onomatopoeia and emotions.

\section{4. Identify the practical issues}

Practical issues to be addressed are related to selection of subjects, process and scheduling.

\subsubsection{Selection of subjects}

For selection of the subject, an intentional nonprobability sample was presented. The subject has balanced characteristics between genders in order to enable comparisons and offer reliable results. The size of the sample followed the recommendations of various authors, which consider costs, to avoid the repetition of the results (NIELSEN and LORANGER, 2007), so as short implementation time line (MATTAR, 1999).

Therefore, for this experiment 12 blind subjects were invited. To enable a broad representation of the subjects, they were chosen among three age groups of the Brazilian population, from 18 to 75 years. The first group is 18 to 30 years old; the second is 31 to 52 years and 53 years or more.

These users were found in two NGOs, the
Association for the Integration of the Blind of Santa Catarina, in Florianópolis, and the Association for the Integration of the Visually Impaired People in Joinville, both in the State of Santa Catarina, Brazil. Table 1 presents the subject according to organization, gender and age group.

\begin{tabular}{|l|l|c|c|c|}
\hline \multirow{2}{*}{ Organization } & \multirow{2}{*}{ Gender } & \multicolumn{3}{|c|}{ Age } \\
\cline { 2 - 5 } & & $\mathbf{1 6}-\mathbf{3 1}$ & $\mathbf{3 1} \mathbf{- 5 2}$ & $\mathbf{5 3}$ or + \\
\hline \multirow{2}{*}{ ACIC } & Female & 1 & 1 & 1 \\
\hline AJIDEVI & Male & 1 & 1 & 1 \\
\hline TOTAL & Female & 1 & 1 & 1 \\
\hline
\end{tabular}

Table 1 - Subject characteristics

Font: from the authors, 2016

\subsubsection{Procedure}

The procedure for data collecting was as follows:

b) Presentation of the researcher and main topics of the research

c) Information about ethical issues

d) A familiarization period was given to the subject to have an idea about the eight onomatopoeias

e) The research question was presented 
$16^{\circ}$ USIHC - Congresso Internacional de Ergonomia e Usabilidade de Interfaces Humano Computador

CINAHPA | 2017 - Congresso Internacional de Ambientes Hipermídia para Aprendizagem.

f) One of the 8 emotions is randomly chosen

g) For the emotion chosen:

1. The researcher plays the record of all the onomatopoeias about that emotion

2. The subject may ask to repeat any onomatopoeia

h) The subject is asked about what onomatopoeia represents that emotion.

i) The researcher writes down the result

j) Steps 5 to 7 are conducted sequentially for all the emotions

k) The researcher concludes the issue thanking everybody.

\subsubsection{Scheduling}

The interviews were scheduled according to the possibilities of the organizations, at their place to avoid the need to adapt the atmosphere for the users. Interviews take place in four occasions: two mornings in Florianópolis and two mornings in Joinville.

\subsection{Decide how to deal with the ethical issues}

All the information provided by the subjects is kept confidential and are not disclosed in order to preserve the identity of all those involved. Personal data such as name, numbers of documents or signatures were not requirements. The survey did not involve questions of bioethics. It was short lived and in places chosen by the subjects, either at home, at work or in other place of convenience, following a scheduled timetable.

The research was approved by the Ethics Council of the State of Santa Catarina (Conselho de Ética do Estado de Santa Catarina), Brazil, under the number 39499114.2.0000.0115, on 06/05/2015.
Catarina, Brazil, at ACIC in Florianópolis and AJIDEVI in Joinville. The mentioned survey was applied following the methodology described, with people with visual disability, predominantly with congenital blindness or developed before the age of five, also divided into gender, and divided into three age groups from 18-75 year old.

The experiment focused on the identification of onomatopoeias which best fitted the selected emotion. The researcher began playing all onomatopoeias of the chosen emotion and repeated them all, or one by one when asked. Then the participant chose one of the onomatopoeia that he/she found more suitable for the specific emotion.

In the first section of the research some onomatopoeias did not reach a consensus, then, the onomatopoeias less mentioned were re tested with new subjects until one onomatopoeia reached the consensus. At the total, it was asked 20 blind people until the consensus is reached.

The research tab by gender, age of the users and the emotion named. Each column represents one of the emotions labelled 0 to 7 , where 0 is Affliction, 1 is Discontent, 2 is Depression, 3 is Sleepiness, 4 is Awakening, 5 is Relaxation, 6 is Pleasure and 7 is Excitement. Table 2 shows the citations of the female users.

\subsection{Evaluate, interpret, and present the data}

The survey was done in May 2015 in Santa

Realização:

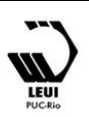


$16^{\circ}$ USIHC - Congresso Internacional de Ergonomia e Usabilidade de Interfaces Humano Computador

CINAHPA | 2017 - Congresso Internacional de Ambientes Hipermídia para Aprendizagem.

\begin{tabular}{|c|c|c|c|c|c|c|c|c|c|}
\hline \multicolumn{2}{|c|}{ FEMALE } & \multirow{2}{*}{ 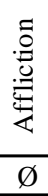 } & \multirow{2}{*}{ 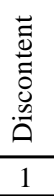 } & \multirow{2}{*}{ 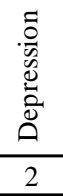 } & \multirow{2}{*}{$\begin{array}{c}\stackrel{w}{0} \\
\stackrel{0}{\Xi} \\
\stackrel{0}{0} \\
\frac{0}{n} \\
3\end{array}$} & \multirow{2}{*}{ 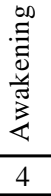 } & \multirow{2}{*}{ 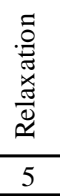 } & \multirow{2}{*}{ 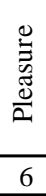 } & \multirow{2}{*}{ 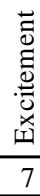 } \\
\hline NGO & AGE & & & & & & & & \\
\hline \multicolumn{10}{|c|}{$\overline{\mathrm{ACIC}}$} \\
\hline & $18-30$ & 5 & 7 & 6 & 1 & 6 & 5 & 6 & 7 \\
\hline & $31-52$ & 3 & 3 & 3 & 1 & 6 & 4 & 6 & 4 \\
\hline & 53 or + & 1 & 3 & 6 & 0 & 1 & 1 & 2 & 4 \\
\hline & 53 or + & 2 & 4 & 2 & 1 & 1 & 5 & 6 & 5 \\
\hline \multicolumn{10}{|c|}{ AJIDEV } \\
\hline & $18-30$ & 1 & 3 & 2 & 1 & 6 & 4 & 6 & 3 \\
\hline & $31-52$ & 5 & 3 & 3 & 1 & 4 & 4 & 6 & 4 \\
\hline & 53 or + & 7 & 7 & 1 & 1 & 7 & 1 & 7 & 4 \\
\hline & $18-30$ & 1 & & 2 & & 3 & 5 & & \\
\hline & $31-52$ & & & 3 & & & 5 & & \\
\hline & 53 or + & 1 & & 3 & & 6 & 6 & & \\
\hline Most & ited & 1 & 3 & 3 & 1 & 6 & 5 & 6 & 4 \\
\hline
\end{tabular}

Table 2 - Citations per Onomatopoeias by Female Users Font: from the authors, 2016

Table 3 shows the citations of the male users.

\begin{tabular}{|c|c|c|c|c|c|c|c|c|c|c|}
\hline \multicolumn{2}{|c|}{ MALE } & \multirow{2}{*}{ 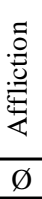 } & \multirow{2}{*}{ 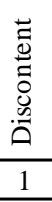 } & \multirow{2}{*}{$\begin{array}{l}0 \\
.0 \\
0 \\
0 \\
0 \\
0 \\
0 \\
\\
\end{array}$} & \multirow{2}{*}{ 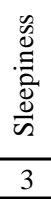 } & \multirow{2}{*}{ 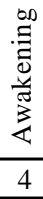 } & \multirow{2}{*}{ 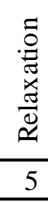 } & \multirow{2}{*}{ 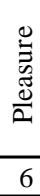 } & \multirow{2}{*}{\multicolumn{2}{|c|}{ 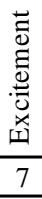 }} \\
\hline NGO & AGE & & & & & & & & & \\
\hline \multicolumn{10}{|c|}{$\overline{\mathrm{ACIC}}$} & \\
\hline & $18-30$ & 1 & 1 & 2 & 1 & 1 & 1 & 1 & & \\
\hline & $31-52$ & 7 & 6 & 4 & 3 & 6 & 1 & 7 & & \\
\hline & 53 or + & 3 & 6 & 1 & 5 & 5 & 1 & 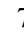 & & \\
\hline & $18-30$ & 2 & 6 & 1 & 3 & 1 & 5 & 3 & & \\
\hline \multicolumn{11}{|c|}{ AJIDEV } \\
\hline & $18-30$ & 2 & 7 & 0 & 3 & 1 & 5 & 2 & & \\
\hline & $31-52$ & & & 2 & & & & & & \\
\hline & 53 or + & 3 & 6 & 4 & 3 & 4 & 1 & & & \\
\hline & $18-30$ & 2 & & 2 & & 1 & & & & \\
\hline & $31-52$ & 2 & & 4 & & & & , & & \\
\hline & 53 or + & 3 & & 4 & & 2 & & 7 & & \\
\hline Most & ited & 2 & 6 & 4 & 3 & 1 & 1 & 1 & & \\
\hline
\end{tabular}

Table 3 - Citations per Onomatopoeias by Male Users Font: from the authors, 2016

As the tables shown, it was possible to identify one onomatopoeia for each one emotion of the Emocard. This definition will lead to the creation of a prototype of a self-report tool that uses onomatopoeia to evaluate digital interfaces.

\section{ANALYSIS OF THE RESULTS}

This section presents the analysis of the results of the onomatopoeia survey. The analysis of onomatopoeias collected was divided by gender because the onomatopoeia and its perception are different for men and women. The results were grouped in two categories:

1st consensus: when four or more people choose the same onomatopoeia;

2nd consensus: when less than four people choose the onomatopoeia.

When no one chooses onomatopoeia, it is discarded.

The onomatopoeias with one, two or three citations were asked again involving new users, until a consensus was achieved.

Analysing women's results, discontent, sleepiness, pleasure and excitement reached a consensus at the first session. Depression and relaxation reached consensus only in the last session. The others, affliction and awakening reached consensus during intermediate sessions.

On the other hand, male survey results reached a consensus at the first session about discontent, sleepiness and relaxation. Depression only reached consensus in the last session. The others, affliction, awakening, relaxation and excitement reached consensus during intermediate sessions.

Based on this analysis, regarding the onomatopoeias expressing discontent and sleepiness, both genders showed consensus in the first session, thus being considered easily identified onomatopoeias. On the other hand, both genders only reached consensus regarding depression during the last session.

Regardless of the initial result and amount of sessions required, it was possible to identify the onomatopoeia of all Emocard 's emotion expressions. Selected emotions were saved in a repository and afterwards assembled in an audio recording studio, creating an onomatopoeic prototype. 


\section{$16^{\circ}$ \\ ERGODESIGN USIHC CINAHPA}

$16^{\circ}$ Ergodesign - Congresso Internacional de Ergonomia e Usabilidade de Interfaces Humano Tecnológica: Produto, Informações Ambientes Construídos e Transporte

$16^{\circ}$ USIHC - Congresso Internacional de Ergonomia e Usabilidade de Interfaces Humano Computador

CINAHPA | 2017 - Congresso Internacional de Ambientes Hipermídia para Aprendizagem.
The both prototypes are available at https://www.youtube.com/watch?v=PGd1Yy025Zk (female) and https://www.youtube.com/watch?v=al_aUMDJ-TI (male) and are free for use.

\section{FINAL CONSIDERATIONS}

The research described in this paper aims to identify onomatopoeia that may be similar to human emotions. Our planning used the structure DECIDE (PREECE, ROGERS and SHARP, 2002) and defined the issues about a qualitative research. It was based on Emocard (DESMET, 2003) a selfreport tool that uses a card with eight human emotions illustrations.

The process began by asking graduate students to write onomatopoeia according to Emocard's. The homophones onomatopoeia were grouped together and sent to an audio recording studio. Recorded onomatopoeia were tested by 20 research subjects, all blind, between 18 and 75 years of age, of both genders.

Each analysed subject listened to the onomatopoeia of every emotion, and then informed the onomatopoeia which best matched the emotion in question. Data were recorded and tabulated, allowing their analysis. All onomatopoeia emotions reached consensus.

According to the analysis, for both genders, discontent and sleepiness were cited reaching consensus at the first session; depression only reached consensus in the last session. The others needed two or three sessions to reach consensus.

Thus the survey defined two issues. The first made it possible to choose an onomatopoeia for each Emocard illustration, which were stored in a repository and forwarded for final editing in an audio studio. Second, the main research question, i.e. if onomatopoeia may be similar to emotions, the answer at the moment is affirmative. It is possible that onomatopoeia may represent human emotions. The research has done a quantitative research with a transcultural validation of onomatopoeia used in the created prototype.
There's still no quantitative results, but the subjects qualify the prototype positively.

\section{BIBLIOGRAPHY}

AGARWAL, Anshu; MEYER, Andrew. Beyond Usability: Evaluating Emotional Response as an Integral Part of the User Experience. In: CHI 2009, 2009., 2009, Boston. New Usability Metrics and Methods. Boston: Acm, 2009. p. 2919 - 2930.

ANCKER, Jessica S.; CHAN, Connie and KUKAFKA, Rita. Interactive Graphics for Expressing Health Risks: Development and Qualitative Evaluation. Journal Of Health Communication: International Perspectives, Londres, 5, n. 14, p.37-41, 23 maio 2012.

BASTIEN, J M Christiain; SCAPIN, Dominique L.. Ergonomic criteria for the evaluation of human computer interfaces. 2.1 France: Institut Nationale de Recherde En Informatique Et En Automitique, 1993. $82 \mathrm{p}$.

BERG, C. H.; Flores, Angela ; Ulbricht, Vânia ; Fadel, L. M. . PESSOAS CEGAS E REPRESENTAÇÃO ESPACIAL: UMA REVISÃO SISTEMÁTICA DE LITERATURA.

Ergodesign \& HCI, v. 3, p. 20-27, 2016.

BERG, Carlos Henrique et al. TESTES DE USABILIDADE EM WEBSITES ACESSÍVEIS In: ERGODESIGN, 12., 2012, Natal. Proceedings... . Natal: Uepa, 2012. p. 1 - 11.

BERG, Carlos Henrique, AVALIAÇÃO DE AMBIENTES VIRTUAIS DE ENSINO APRENDIZAGEM ACESSÍVEIS ATRAVÉS DE TESTES DE USABILIDADE COM EMOÇÕES. 2013. 80 f. Dissertation (Master Degree) Department of Knowledge Engineering and Management, University Federal de Santa Catarina, Florianópolis, 2013.

BERG, Carlos Henrique, FADEL, Luciane Maria; ULBRICHT, Vânia. NONVERBAL USABILITY TESTS WITH EMOTIONS FOR THE VISUALLY IMPAIRED. In: DESIGN E EMOTION 2014, 9., 2014, Bogotá. Proceedings
Realização:

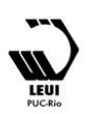




\section{$16^{\circ}$ \\ ERGODESIGN USIHC CINAHPA}

$16^{\circ}$ Ergodesign - Congresso Internacional de Ergonomia e Usabilidade de Interfaces Humano Tecnológica: Produto, Informações Ambientes Construídos e Transporte

$16^{\circ}$ USIHC - Congresso Internacional de Ergonomia e Usabilidade de Interfaces Humano Computador

CINAHPA | 2017 - Congresso Internacional de Ambientes Hipermídia para Aprendizagem. the Colors of Care. Bogotá: Ediciones Uniandes, 2014. p. 394 - 399.

DESMET, P.M.A. (2003). Measuring emotion: Development and application of an instrument to measure emotional responses to products. In M.A. Blythe, A.F. Monk, K. Overbeeke, and P.C. Wright (Eds.), Funology: From usability to enjoyment. (pp. 111-123). Dordrecht: Kluwer Academic Publishers.

KATSIONIS, George; VIRVOU, Maria. Adapting OCC theory for affect perception in educational software. Available in:

$<$ http://gkatsion.kman.gr/2005/2005-HCI-

USA/HCI-2005_KatsionisVirvou.pdf>. Access em: 13 jul. 2012.

MATTAR, Fauze Najib. Pesquisa de marketing: metodologia, planejamento. 5 ed. São Paulo: Atlas, 1999.

NIELSEN, J. e LORANGER, H. Usability in the Web: projecting websites with qualified, Rio de Janeiro: Elsiever, 2007. 406 p.

NIELSEN, J., Usability Engineering, Academic Press Limited, London, 1993.

NIELSEN, Jakob. Technology Transfer of Heuristic Evaluation and Usability Inspection. In: INTERNATIONAL CONFERENCE ON HUMAN-COMPUTER INTERACTION, 95., 1995, Lillehammer. IFIP INTERACT.

Lillehammer: International Conference On Humancomputer Interaction, 1995. p. 1 - 9.

PREECE, Jenny; ROGERS, Yvonne; SHARP, Helen. Interaction Design: Beyond HumanComputer Interaction. Maryland: Univ. Of Maryland, 2002. 552 p.

RÖDER, B. e RÖSLER, F., Memory for environmental sounds in sighted, congenitally blind and late blind adults: evidence for crossmodal compensation. International Journal of Psychophysiology, 50, 27-39, 2003

SAUER, Juergen; SONDEREGGER, Andreas. The influence of prototype fidelity and aesthetics of design in usability tests: Effects on user behaviour, subjective evaluation and emotion. Applied Ergonomics, Fribourg, n. 40, p.670-677, 18 jun. 2008.

TOGNAZZINI, Bruce. TOG on Interface. Boston: Addisonwesley Longman Publishing Co, 1992. $352 \mathrm{p}$.

TZVETANOVA, Sylvia; TANG, Ming-xi e JUSTICE, Lorraine. Emotional Web Usability Evaluation. Human-Computer Interaction: HCII 2007, Berlin, p.1039-1046, 2007

WORLD WIDE WEB CONSORTIUM. WCAG 1.0: Web Content Accessibility Guidelines 1.0. São Paulo: World Wide Web Consortium, 1999. 1 p. Available in: <http://www.w3.org/TR/WCAG10 05 ago. 2014.

WORLD WIDE WEB CONSORTIUM. WCAG 2.0: Web Content Accessibility Guidelines

(WCAG) 2.0. 1 ed. São Paulo: World Wide Web Consortium, 2008. 1 p. Available em: <http://www.w3.org/TR/WCAG20/>. Access em: 5 ago. 2014.

\section{Acknowledgements}

This research is supported by CAPES/CNPQ

Brazil.

Thanks to Romy B. Dunzinger
Realização:

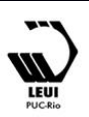

